\title{
Sakubitril/valsartan kalp yetersizliği olgularında yaşam beklentisini ne kadar uzatır?
}

\author{
DD Dr. Murat Akçay, (1) Dr. Serkan Yüksel \\ Ondokuz Mayıs Üniversitesi Tıp Fakültesi, Kardiyoloji Anabilim Dalı, Samsun
}

PARADIGM-HF çalışmasında, düşük ejeksiyon fraksiyonlu kalp yetersizliği (KY) hastalarında sakubitril/valsartan'ın kardiyovasküler nedenli ölüm oranları ve KY nedenli hastaneye yatışları azaltmada enalapril'den daha üstün olduğu gösterilmiştir. ${ }^{[1]}$ Ancak, klinik çalışmalardan bu yararın uzun vadede korunup korunmadığ 1 ve bu yararla ilgili hangi mekanizmaların ön planda olduğu belirsizliğini korumaktadır. Bu amaçla PARADIGM-HF çalışmasından birçok alt grup analizi yapılmıştır. Yapılan bir post-hoc analizde, ilk olay sırasındaki yaşa bağlı olay oranları tahmini ve yaşa göre beklenen sağkalım süreleri elde edilmiştir. ${ }^{[1,2]}$ Kaplan-Meier sağkalım analizinde, zaman ölçeği olarak yaş tahmin edilmiş ve sağkalım eğrisinin altındaki alan üzerinden olaysız sağkalım hesaplanmıştır. Sonuçlar, SOLVD-T (Studies of Left Ventricular Dysfunction-Treatment) çalışmasından elde edilen uzun süreli sağkalım verilerine göre doğrulanmıştır. Elli beş yaşında bir hastada, enalapril'e randomize edilirse yaşam beklentisinin 11.6 yıl, sakubitril/valsartan'a randomize edilmesi durumunda 12.9 yıl (\%95 Güven Aralığı: -0.1 ile 2.8) olacağı öngörülmüştür. Altmış beş yaşında bir hastada ise, enalapril ile 10 yıl ek yaşam beklentisi öngörülmüşken, sakubitril/valsartan'a randomizasyon ile 11.4 y1l ek yaşam beklentisi öngörmüştür (\%95 Güven Aralığ1: 0.3-2.4) (Şekil 1). Birincil sonlanım noktası için, 55 yaşında ve 65 yaşında bir hastanın, enalapril yerine sakubitril/valsartan'a randomize edildiği takdirde, olaysız hayatta kalma süresinin sirasıyla 2.1 ve 1.6 yıl olduğu tahmin edilmektedir ${ }^{[1,2]}$ (Şekil 2). Bu yeni analiz yöntemi, standart tedaviye kıyasla sakubitril/ valsartan'ın uzun dönem klinik faydası hakkında bize yeni bakış açısı sunmaktadır. Ancak bu çalışma tasarımı, öngörülen bir yararı uzun vadede tahmin etmek için mevcut kısa vadeli takip verilerinden tahmin yapmaktadır. Bu yüzden, bu bulgular uzun süreli sakubitril/valsartan kullanımı sırasında, faydalı etkilerinin sabit kaldığ 1 varsayımı ile sınırlıdır. Yine, SOLVD-T çalışmasında, PARADIGM-HF çalışmasındaki gibi enalapril ve benzer dozlama şeması kullanılmasına rağmen hastalarda sınırlı beta-bloker kullanımı ve bilinmeyen mineralokortikoid antagonisti kullanımı gibi bazı özelliklerde farklılıklar mevcuttur. ${ }^{[2,3]}$

Bazal karakteristikler, ko-morbiditeler gibi özelliklere göre yüksek riskli KY grubundaki hastalarda sakubitril/valsartan' in enalapril tedavisine üstünlüğü en yüksek oranda saptanmıştır. Bu hastalar 2 yıl boyunca enalapril yerine sakubitril/valsartan ile tedavi edilirse, 100 hastada 7 hasta daha az kardiyovasküler nedenli ölüm ve KY nedenli hastaneye yatış birincil sonlanımlarını yaşayacağ 1 saptanmıştır. ${ }^{[1,4]} \mathrm{Bir}$ post-hoc analizde, sol ventrikül ejeksiyon fraksiyonu ile KY nedenli hastaneye yatışlar, kardiyovasküler ölüm arasında belirgin korelasyon varken, sakubitril/ valsartan'in olumlu etkilerinin ejeksiyon fraksiyonundan etkilenmediği saptanmıştır. Ayrıca sakubitril/ valsartan'ın primer son noktalar açısından enalapril'e üstünlüğü, bazal ejeksiyon fraksiyonunun etkisinden bağımsız devam etmiştir. ${ }^{[2,5]}$ Ayaktan tedavi gören stabil KY hastalarında ilk basamak tedavi olarak ACE inhibitörü ya da anjiyotensin reseptör blokeri başlanması, kötüleşen semptomları ve son zamanlarda hastaneye yatışları sık olanlarda ise sakubitril/ valsartan tedavisi başlanması yaklaşımı varken, posthoc analizde ayaktan stabil hastalarda da en az kötüleșen semptomları olan KY hastaları kadar klinik yarar sağlandığ 1 saptanmıştır. ${ }^{[2]}$ Başka bir post-hoc analizde, ölümlerin \%80.9'u ani kardiyak ölüm ve kötüleşen KY nedeniyle meydana gelmiş ve enalapril ile karşılaştırıldığında sakubitril/valsartan tedavi grubunda bunlarda anlamlı derecede düşük saptanmıştır. ${ }^{[2,6]}$ Malignite, enfeksiyon gibi kardiyovasküler neden dışı ölümlerde ise iki tedavi grubu arasında farklılık saptanmamıştır..$^{[2,6]}$ Yine başka bir post-hoc analizde, hastaların \%43'ünde miyokart enfarktüsü, \%57‘sinde 
55 yaşından sonra sağkalım

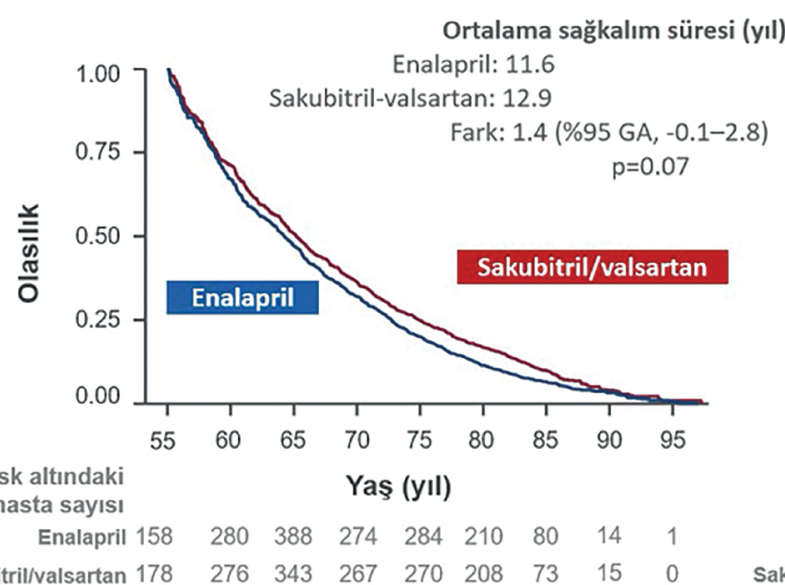

65 yaşından sonra sağkalım

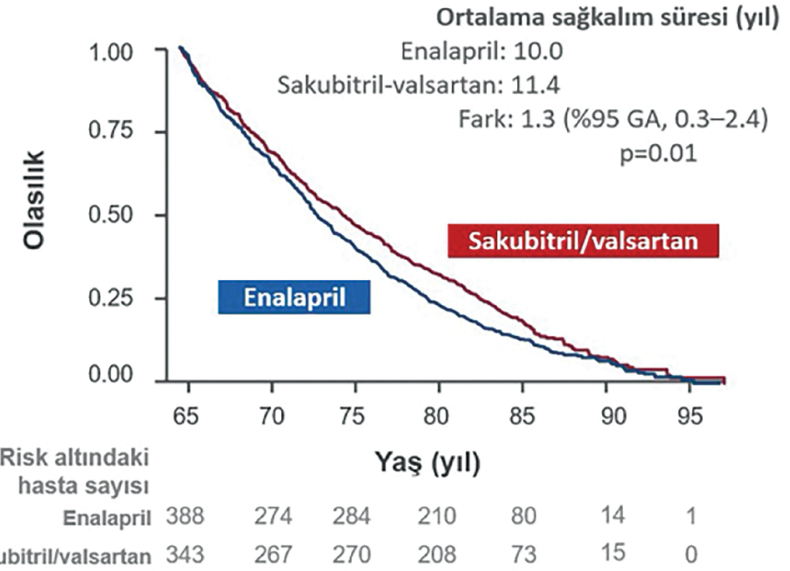

Yașa göre Kaplan-Meier eŏrileri gösterilmektedir. Gruplar arası farklılıklar sayıların yuvarlanması nedeniyle basit sayısal farklııklar olmayabilir. Risk altındaki hasta sayısı, belirli bir yașta ilgili olayın meydana gelmediği PARADIGM-HF çalışmasına kayıtlı hasta sayısını gösterir.

1. Clagget B, et al. N Engl J Med 2015;373:2289-2290.

Şekil 1. Yaş grubuna göre PARADIGM-HF çalışmasında öngörülen herhangi bir nedene bağlı ölüm olasılığı.

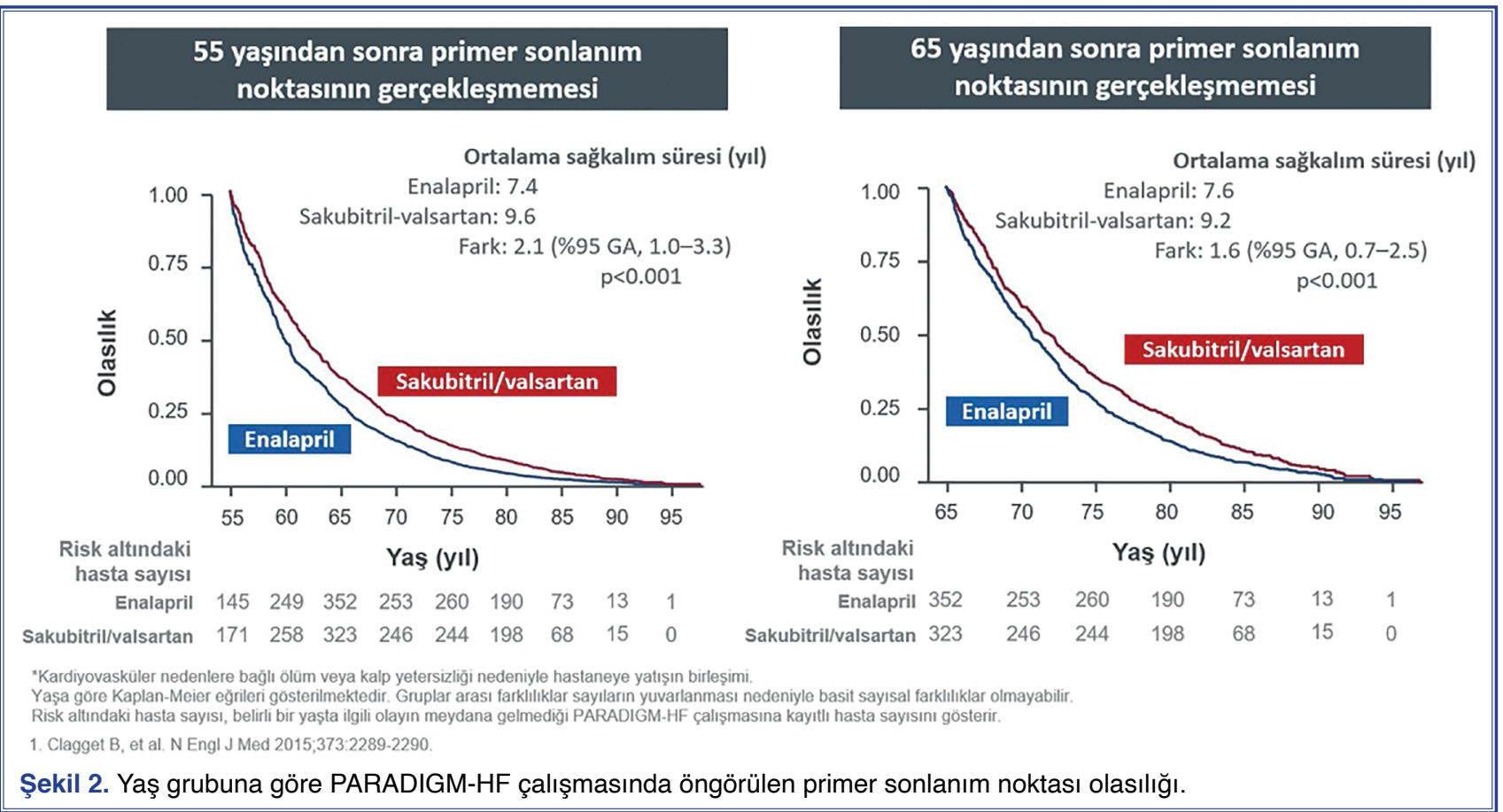

koroner arter hastalığı öyküsü olup, koroner açıdan riskli olan bu hasta grubunda, koroner olaylar sakubitril/valsartan tedavi grubunda enalapril'e göre anlamlı derecede daha az saptanmıştır (Risk Oranı: 0.83,\%95 Güven aralığı: 0.75-0.92)..$^{[2,7]}$ KYnin klinik ilerlemesi, sık diüretik ve inotrop gibi intravenöz ilaç ihtiyac1, acile sık başvuru ve yatışlar açısından yapılan bir post-hoc analizde, sakubitril/valsartan'ın enalapril'e göre anlamlı derecede üstün olduğu saptanmıştır. ${ }^{[2,8]}$ KY nedenli hastanede yatışlarla bazal sistolik kan basıncı arasında U-eğrisi şeklinde ilişki saptanmış olup, sistolik kan basınc1 $<110 \mathrm{mmHg}, 110$ ila $120 \mathrm{mmHg}$ ve $\geq 140 \mathrm{mmHg}$ olanlarda sık olay izlenmiştir. Sakubitril/valsartan tüm bazal kan basıncı gruplarında da primer sonlanım noktaları açısından enalapril'e göre daha faydalı bulunmuştur. ${ }^{[2,9]}$ Tüm bu post-hoc analiz- 
ler, sakubitril/valsartan'nın yaşam beklentisini uzatmadaki etkisini ortaya koymaktadır.

PARADIGM-HF çalışmasının yayınlanmasından sonra sakubitril/valsartan'ın etki mekanizmaları, klinik yararlarının büyüklüğü göz önüne alındığında, KYnin bakım ve tedavisi yeni baştan şekillenmeye başlamıştır. ${ }^{[1,2]}$ PARADIGM-HF çalışmasının son zamanlardaki post-hoc analiz sonuçları ise, enalapril'e göre daha yüksek risk skorlu KY hastalarındaki faydası, kardiyak yapı ve mekanikteki iyileşme ile pompa bozukluğunda düzelme, tekrar hastaneye yatışlarda azalma, koroner olaylardan ölümlerde azalma, diüretik ihtiyacında azalmaya yol açması, diyabetik hastalarda glisemik kontrolün iyileştiğinin gösterilmesi, mineralokortikoid kullanan hastalarda daha az hiperkalemi görülmesi, bilişsel fonksiyonların kötüleştiğine dair bir bulgunun olmaması, tüm yaş gruplarında enalapril'den daha yararlı olduğu ve hastalardaki bölgesel farklılıklara rağmen yararın devam ettiği gösterilmiştir. ${ }^{[1,2]}$ Ancak, bu post-hoc analizlerden elde edilen sonuçlar, hipotez oluşturdukları için dikkatle yorumlanmalı ve tüm bu bulguların yeterince güçlü prospektif çalışmalar ile doğrulanması gerekmektedir. Yine, sakubitril/valsartan tedavisinin kesilmesinin başlıca nedenleri hipotansiyon ve böbrek fonksiyon bozukluğu olması nedeniyle, bu tür hastalarda tedaviye dikkatle başlanılması unutulmamalıdır. KY tedavisine yaklaşımımızdaki mevcut anlayışımız göz önüne alındığında, yeni post-hoc analizler ve bunların yorumları ile yaşam beklentisindeki değişimler ve devam eden prospektif çalışmaların sonuçlarını değerlendirmek heyecan verici olacaktır.

\section{Kaynaklar}

1. Claggett B, Packer M, McMurray JJ, Swedberg K, Rouleau J, Zile MR, et al. Estimating the Long-Term Treatment Benefits of Sacubitril-Valsartan. N Engl J Med 2015;373:2289-90.

2. Smith KR, Hsu CC, Berei TJ, Aldemerdash A, Hollis IB, Vardeny O, Rodgers JE. PARADIGM-HF Trial: Secondary Analyses Address Unanswered Questions. Pharmacotherapy 2018;38:284-98.

3. SOLVD Investigators, Yusuf S, Pitt B, Davis CE, Hood WB, Cohn $\mathrm{JN}$. Effect of enalapril on survival in patients with reduced left ventricular ejection fractions and congestive heart failure. N Engl J Med 1991;325):293-302.

4. Simpson J, Jhund PS, Silva Cardoso J, Martinez F, Mosterd A, Ramires F, et al. Comparing LCZ696 with enalapril according to baseline risk using the MAGGIC and EMPHASIS-HF risk scores: an analysis of mortality and morbidity in PARADIGM-HF. J Am Coll Cardiol 2015;66:2059-71.

5. Solomon SD, Claggett B, Desai AS, Packer M, Zile M, Swedberg $\mathrm{K}$, et al. Influence of Ejection Fraction on Outcomes and Efficacy of Sacubitril/Valsartan (LCZ696) in Heart Failure with Reduced Ejection Fraction: The Prospective Comparison of ARNI with ACEI to Determine Impact on Global Mortality and Morbidity in Heart Failure (PARADIGM-HF) Trial. Circ Heart Fail 2016;9:e002744.

6. Desai AS, McMurray JJ, Packer M, Swedberg K, Rouleau JL, Chen F, et al. Effect of the angiotensin-receptor-neprilysin inhibitor LCZ696 compared with enalapril on mode of death in heart failure patients. Eur Heart J 2015;36:1990-7.

7. Mogensen UM, Køber L, Kristensen SL, Jhund PS, Gong J, Lefkowitz MP, et al. The effects of sacubitril/valsartan on coronary outcomes in PARADIGM-HF. Am Heart J 2017;188:35-41.

8. Packer M, McMurray JJ, Desai AS, Gong J, Lefkowitz MP, Rizkala AR, et al. Angiotensin receptor neprilysin inhibition compared with enalapril on the risk of clinical progression in surviving patients with heart failure. Circulation 2015;131:54-61.

9. Böhm M, Young R, Jhund PS, Solomon SD, Gong J, Lefkowitz MP, et al. Systolic blood pressure, cardiovascular outcomes and efficacy and safety of sacubitril/valsartan (LCZ696) in patients with chronic heart failure and reduced ejection fraction: results from PARADIGM-HF. Eur Heart J 2017;38:1132-43. 